\title{
INHIBITION OF CHOLINE ACETYLTRANSFERASE BY MONOCLONAL ANTIBODIES
}

\author{
WILLIAM L. STRAUSS AND MARSHALL NIRENBERG \\ Laboratory of Biochemical Genetics, National Heart, Lung, and Blood Institute, National Institutes of Health, Bethesda, \\ Maryland 20205
}

Received March 21, 1984; Revised June 12, 1984; Accepted June 15, 1984

\begin{abstract}
Four monoclonal antibodies were obtained to rat brain choline acetyltransferase (CAT). The enzyme was purified 95,000-fold from rat brain by precipitation with acetic acid at $\mathrm{pH} 4.5$, fractionation with 40 to $60 \%$ $\left(\mathrm{NH}_{4}\right)_{2} \mathrm{SO}_{4}, \mathrm{CM}$-Sephadex chromatography, and affinity column chromatography on agarose-hexane-coenzyme A. The enzyme preparation was applied to the affinity column in the presence of $10 \mathrm{mM}$ acetylcholine to increase the affinity of CAT for coenzyme A; the enzyme then was eluted with $10 \mathrm{mM}$ acetyl coenzyme A. Fusion of P3X63 Ag8 myeloma cells with spleen cells isolated from a BALB/c mouse that had been immunized with affinity-purified CAT with a specific activity of $29.4 \mu \mathrm{mol}$ of ACh synthesized $/ \mathrm{min} / \mathrm{mg}$ of protein resulted in the isolation of four hybridomas synthesizing antibodies to CAT that inhibit the activity of the enzyme. Anti-CAT 1 or 2 inhibits CAT activity $100 \%$. At the highest antibody concentration tested, anti-CAT 3 inhibited acetylcholine synthesis $80 \%$. Hybridoma antibody-dependent inhibition of CAT activity was reversed by dissociation of immune complexes via dilution, demonstrating that antibody binding does not irreversibly alter the structure of the enzyme. When bound to [rabbit anti-mouse IgG-protein A Staphylococcus aureus] complexes, anti-CAT 1,3 , and 4 each were effective reagents for the precipitation of CAT activity from solution. Thirty-one to $53 \%$ of the precipitated enzyme was recovered following the dissociation of immune complexes. Anti-CAT 1, 2, and 3 inhibit CAT from 18-day chick embryo brain, NS20-Y mouse neuroblastoma cells, and rat brain.
\end{abstract}

Choline acetyltransferase (CAT, acetyl-CoA:choline $O$-acetyltransferase, EC 2.3.1.6), which catalyzes the synthesis of acetylcholine, is a phenotypically specific marker for cholinergic neurons. Numerous studies have demonstrated that expression of the gene for this enzyme is regulated by environmental factors (Le Douarin, 1980; Walicke et al., 1977; Patterson, 1980). A 45,000-dalton macromolecule synthesized by cardiac muscle or $\mathrm{C} 6$ glioma cells has been reported to increase the synthesis of acetylcholine and decrease the synthesis of catecholamines in cultures of neonatal rat superior cervical ganglion neurons (Weber, 1981). Enzyme- and gene-specific probes would facilitate a direct examination of the molecular events which underlie these phenomena. Conventional approaches to the isolation of monospecific antibodies or cDNA clones for CAT would be technically difficult because this enzyme has been estimated to comprise less than $0.001 \%$ of the protein in brain (Eckenstein et al., 1981). We have chosen as an alternative the preparation of monoclonal antibodies to CAT for use as reagents for the immunological screening of cDNA expression libraries. During the course of these studies, several reports appeared which describe the isolation of hybridomas secreting antibodies to choline acetyltransferase from rat (Park et al., 1982; Crawford et al., 1982; Ichikawa et al., 1983), bovine (Levey et al., 1981, 1983), and Drosophila brain (Crawford et al., 1982a). In the present study, we describe an improved affinity chromatography method for the purification of CAT from rat brain and the properties of four monoclonal antibodies that bind to rat, chick, and mouse CAT and inhibit the activity of the enzyme.

\section{Materials and Methods}

Production of monoclonal antibodies. Eleven female BALB/c mice each were injected intraperitoneally with $1.5 \mu \mathrm{g}$ of affinity-purified CA'T (estimated to be $65 \%$ pure) in $0.2 \mathrm{ml}$ of $10 \mathrm{~mm}$ sodium phosphate, adjusted to $\mathrm{pH} 7.2$ with citric acid, $0.1 \mathrm{mM}$ EDTA, $0.1 \mathrm{~mm}$ dithiothreitol (buffer A) containing $10 \mathrm{~mm}$ acetyl coenzyme A, $20 \%$ ethylene glycol, and $200 \mathrm{~mm} \mathrm{NaCl}$ as a 1:1 emulsion with incomplete Freund's adjuvant on both days 0 and 15 . Serum was collected from the tail of each mouse on day 56 and allowed to clot overnight, and a $10-\mu$ l portion of the supernatant was assayed for the ability to inhibit the activity of $1 \mathrm{ng}$ of CAT purified by CM-Sephadex chromatography (1.4 $\mu \mathrm{g}$ of protein/ reaction mixture). Unless otherwise stated, antibody was incubated with enzyme at $4^{\circ} \mathrm{C}$ for 18 to $20 \mathrm{hr}$. Longer incubations did not result in additional inhibition of the enzyme.

One of the 11 sera assayed inhibited CAT and this mouse was injected intraperitoneally with $9 \mu \mathrm{g}$ of affinity-purified enzyme preparation in $1 \mathrm{ml}$ of Dulbecco's phosphate-buffered saline (PBS) on day 58 and again on day 60. On day 61 , spleen cells $\left(10^{8}\right)$ were fused (Galfre et al., 1977) with $2 \times 10^{7} \mathrm{P} 3 \mathrm{X} 63 \mathrm{Ag} 8$ myeloma cells and cultured in selective medium containing hypoxanthine, aminopterin, and thymidine as described previously (Trisler et al., 1981).

Assay of anti-CAT antibodies. Aliquots $(125 \mu \mathrm{l})$ of medium conditioned for 2 days by hybridoma cells or of a 25 -fold concentrated protein fraction prepared as described below supplemented with $1 \%$ IgG-free fetal bovine serum were incubated with $25 \mu \mathrm{l}$ of partially purified CAT in PBS and 1\% IgG-free fetal bovine serum for 18 to 20 $\mathrm{hr}$ at $4^{\circ} \mathrm{C}$. The concentration of CAT in this incubation mixture varied depending on the objective of the experiment. Most assays contained approximately 1 to $2 \mathrm{ng}$ of CAT protein with a specific activity of approximately $33 \mathrm{nmol}$ of ACh formed $/ \mathrm{min} / \mathrm{mg}$ of protein. Enzyme activity was assayed in triplicate by the procedure of Schrier et al. 
(1974). Each reaction mixture contained $40 \mu \mathrm{l}$ of enzyme/antibody mixture, $10 \mathrm{~mm}$ potassium phosphate, $\mathrm{pH} 7.2,0.2 \mathrm{~mm}$ EDTA, $0.1 \mathrm{~mm}$ eserine sulfate, $2 \mathrm{mM}$ choline chloride, and $0.202 \mathrm{mM}\left[1-{ }^{14} \mathrm{C}\right]$ acetyl coenzyme A $(190,000 \mathrm{cpm})$ in a final volume of $50 \mu \mathrm{l}$. The reaction mixture was incubated at $37^{\circ} \mathrm{C}$ for 10 or $15 \mathrm{~min}$, and then $950 \mu \mathrm{l}$ of icecold $\mathrm{H}_{2} \mathrm{O}$ was added. The mixture was passed through a column of AG1-X8 (chloride form, 100-200 mesh) and radioactivity in the eluate was determined with $10 \mathrm{ml}$ of Maxifluor in a Beckman scintillation counter.

Antibody preparations. Cultures of the hybridomas synthesizing antibodies to CAT or of the parent myeloma were grown in $850-\mathrm{cm}^{2}$ roller bottles at $37^{\circ} \mathrm{C}$ in Dulbecco's modification of Eagle's medium without $\mathrm{NaHCO}_{3}$ (4.5 g of dextrose/liter; GIBCO catalog no. 430-2100) supplemented with $15 \mathrm{~mm}$ Hepes (sodium salt), $\mathrm{pH} \mathrm{7.4,2 \%} \mathrm{IgG-free} \mathrm{fetal}$ bovine serum, $10 \%$ NCTC $109,0.1 \mathrm{mM}$ of each nonessential amino acid (GIBCO catalog no. 320-1110), 2 milliunits of insulin $/ \mathrm{ml}, 1 \mathrm{mM}$ glutamine, $1 \mathrm{~mm}$ oxalacetic acid, $0.1 \mathrm{~mm}$ hypoxanthine, and $16 \mu \mathrm{M}$ thymidine. The osmolarity of the medium was adjusted to 340 mosm with $\mathrm{NaCl}$. One hundred-ml cultures containing $5 \times 10^{5}$ cells $/ \mathrm{ml}$ were expanded by the addition of fresh medium to a final volume of $800 \mathrm{ml}$. The medium was collected by centrifugation at $4000 \times \mathrm{g}$ for $10 \mathrm{~min}$, frozen, and stored at $-20^{\circ} \mathrm{C}$. For the harvesting of antibody, the medium

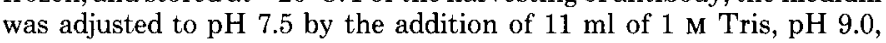
per liter of medium. Proteins were precipitated at $4^{\circ} \mathrm{C}$ by the addition of solid $\left(\mathrm{NH}_{4}\right)_{2} \mathrm{SO}_{4}$ to $70 \%$ saturation and stirred for $1 \mathrm{hr}$. Following centrifugation for $90 \mathrm{~min}$ at $4000 \times \mathrm{g}$, the precipitated proteins were dissolved in PBS $(0.5$ to $2 \%$ of the original volume), desalted by passage through a column of Sephadex G-25 in PBS, and stored over liquid $\mathrm{N}_{2}$. For three of the antibodies described below, the recovery of active immunoglobulin from this procedure was greater than $90 \%$. However, antibody synthesized by a fourth hybridoma (anti-CAT 4) was not recovered in an active form.

General. Protein was determined by a modification of the method of Lowry and co-workers (1951) except in the case of affinity-purified CAT which was measured by the fluorescamine assay of Böhlen et al. (1973). Bovine serum albumin (crystallized three times) was used as the standard. SDS-polyacrylamide gel electrophoresis was performed according to the method of Laemmli (1970) and proteins were stained with silver ions as described by Merill et al. (1981).

Materials. Agarose CoA type I and acetyl coenzyme A, lithium salt, were obtained from P-L Biochemicals. Rabbit anti-mouse IgG was obtained from Miles Laboratories. Calbiochem was the source for formalin-fixed Staphylococcus aureus (Pansorbin) and for eserine sulfate. $\mathrm{AG} 1-\mathrm{X} 8$ anion exchange resin was obtained from Bio-Rad. $\left[1-{ }^{14} \mathrm{C}\right]$ Acetyl coenzyme A was purchased from either New England Nuclear or Amersham. Roche Diagnostics was the source for fluorescamine. Oxalacetic acid and insulin were from Boehringer-Mannheim and Sigma, respectively. NCTC 109 medium was obtained from M. A. Bioproducts. All other tissue culture reagents were from GIBCO.

\section{Results}

CAT purification. A summary of the purification of rat brain CAT is presented in Table $\mathrm{I}$. The procedures through step 5 were essentially those of Ryan and McClure (1979) with minor modifications as described below. Brains were removed from adult, female Sprague-Dawley rats, frozen in dry ice, and stored over liquid nitrogen until used. All subsequent procedures were at 0 to $4^{\circ} \mathrm{C}$.

Homogenization. Three hundred grams of whole rat brain were thawed in $950 \mathrm{ml}$ of $25 \mathrm{mM}$ sodium phosphate, $\mathrm{pH} 7.4$, and minced with scissors. Portions $(100 \mathrm{ml})$ of the suspension were homogenized for $30 \mathrm{sec}$ in a Brinkmann Polytron using a generator setting of 4 and then by two strokes at $2000 \mathrm{rpm}$ in a Potter-Elvehjem homogenizer. The homogenate was centrifuged for $1 \mathrm{hr}$ at $20,000 \times g$; the supernatant fraction was removed and the pellet was discarded.

Acid precipitation. The $\mathrm{pH}$ of the $20,000 \times \mathrm{g}$ supernatant fraction $(905 \mathrm{ml})$ was adjusted gradually to 4.5 with $6.4 \mathrm{ml}$ of $8.7 \mathrm{~N}$ acetic acid. The suspension was stirred for $1 \mathrm{hr}$ and centrifuged for $20 \mathrm{~min}$ at $20,000 \times \mathrm{g}$. The supernatant fraction was decanted and adjusted to $\mathrm{pH} 6.0$ with $1 \mathrm{~N} \mathrm{NaOH}$.

Ammonium sulfate fractionation. Without further $\mathrm{pH}$ adjustment, solid $\left(\mathrm{NH}_{4}\right)_{2} \mathrm{SO}_{4}$ was added to $40 \%$ saturation. The suspension was stirred for $30 \mathrm{~min}$ and centrifuged at $20,000 \times$ $g$ for $20 \mathrm{~min}$. The supernatant fraction was adjusted to $60 \%$ $\left(\mathrm{NH}_{4}\right)_{2} \mathrm{SO}_{4}$ saturation, stirred for $30 \mathrm{~min}$, and, again, centrifuged at $20,000 \times g$ for $20 \mathrm{~min}$; the pellets were dissolved in 30 $\mathrm{ml}$ of buffer $\mathrm{A}$ and dialyzed overnight against 4 liters of buffer A.

CM-Sephadex chromatography. The dialyzed enzyme preparation was fractionated further on a carboxymethyl-Sephadex column $(2.5 \times 16 \mathrm{~cm})$ equilibrated with buffer A. Protein was eluted with a $600-\mathrm{ml}$ linear gradient of 0 to $200 \mathrm{mM} \mathrm{NaCl}$ in buffer $\mathrm{A}$ at $25 \mathrm{ml} / \mathrm{hr}$. Four-ml fractions were collected. CAT peak fractions were pooled and concentrated by precipitation with $60 \%\left(\mathrm{NH}_{4}\right)_{2} \mathrm{SO}_{4}$. Following centrifugation, the pellet was suspended in $2 \mathrm{ml}$ of buffer $\mathrm{A}$ and residual traces of $\left(\mathrm{NH}_{4}\right)_{2} \mathrm{SO}_{4}$ were removed by passage through a column of Sephadex G-25 in buffer $\mathrm{A}$. The resulting enzyme preparation was stored at $-20^{\circ} \mathrm{C}$

Agarose-CoA chromatography. The final purification step was affinity chromatography using coenzyme A coupled to an agarose-hexanoic acid support by carbodiimide reaction without affecting the sulfhydryl (SH) group of coenzyme A. The structure of the covalently coupled [ligand-sidearm] product of the reaction has not been identified. However, coenzyme A probably is attached to the hexanoic acid sidearm primarily through the 6-amino group of the adenosine residue and perhaps to a lesser extent via the 2 '-hydroxyl of the ribosyl moiety. Coupling the $\mathrm{SH}$ group of coenzyme A to the carboxyl group of the sidearm via thioester bonds markedly reduced the effectiveness of the resin for the purification of CAT (not shown). Each time that the affinity column with free SH groups was to be used, the column $(1 \times 6.4 \mathrm{~cm})$ was washed with $20 \mathrm{ml}$ of $20 \mathrm{mM}$ dithiothreitol, $10 \mathrm{~mm}$ Tris- $\mathrm{HCl}, 300 \mathrm{~mm} \mathrm{NaCl}$, and $1 \mathrm{~mm}$ EDTA to reduce disulfide bonds, and then washed and equilibrated with buffer A containing $20 \%$ ethylene glycol, $200 \mathrm{~mm} \mathrm{NaCl}$, and $10 \mathrm{mM}$ acetylcholine chloride (buffer B). Acetylcholine was

TABLE I

Purification of choline acetyltransferase from rat brain

\begin{tabular}{|c|c|c|c|c|c|}
\hline \multirow[b]{2}{*}{ Fraction } & \multicolumn{2}{|c|}{ Total } & \multirow{2}{*}{$\begin{array}{l}\text { Specific Activity } \\
{\left[{ }^{14} \mathrm{C}\right] \mathrm{ACh} \text { Formed }}\end{array}$} & \multirow[b]{2}{*}{$\begin{array}{c}\text { CAT Activity } \\
\text { Recovered }\end{array}$} & \multirow[b]{2}{*}{ Purification } \\
\hline & $\begin{array}{l}{\left[{ }^{21} \mathrm{C}\right] \mathrm{ACh}} \\
\text { Formed }\end{array}$ & Protein & & & \\
\hline & $\mathrm{nmol} / \mathrm{min}$ & $m g$ & $\mathrm{nmol} / \mathrm{min} / \mathrm{mg}$ protein & $\%$ & fold \\
\hline $20,000 \times g$ supernatant & 6,000 & 10,300 & 0.583 & 51 & 1.9 \\
\hline pH 4.5 supernatant & 4,590 & 4,340 & 1.06 & 39 & 3.4 \\
\hline $40-60 \%\left(\mathrm{NH}_{4}\right)_{2} \mathrm{SO}_{4}$ precipitated & 3,230 & 787 & 4.10 & 27 & 13.3 \\
\hline
\end{tabular}

${ }^{a}$ Details of the experimental procedures are presented in the text. The homogenate was prepared from $315 \mathrm{gm}$ of rat brain.

${ }^{b}$ The CM-Sephadex fraction was affinity-purified in three equal portions. 
included to increase the affinity of CAT for the coenzyme A affinity ligand through allosteric interactions (White and $\mathrm{Wu}$, 1973). One $\mathrm{ml}$ of the CM-Sephadex CAT fraction $(16 \mathrm{mg}$ of protein) was diluted with $9 \mathrm{ml}$ of buffer B and applied to the column at $12 \mathrm{ml} / \mathrm{hr}$. The column then was washed with $20 \mathrm{ml}$ of buffer B. Under these conditions, essentially all of the enzyme, but very little other protein, was retained by the column (Fig. 1). Eighty-seven per cent of the applied CAT was eluted from the column with $10 \mathrm{ml}$ of buffer A containing 10 mM acetyl coenzyme A (lithium salt), $20 \%$ ethylene glycol, and $200 \mathrm{~mm} \mathrm{NaCl}$.

Affinity-purified CAT was iodinated using ${ }^{125} \mathrm{I}$-labeled-Bolton-Hunter reagent, subjected to SDS-polyacrylamide gel electrophoresis, and detected either by autoradiography (not shown) or by staining with silver ions (Fig. 1, inset). One major band of protein was detected with an $M_{\mathrm{r}}$ of 68,000 . Four minor protein bands of lower molecular weight were detected on autoradiograms. Analysis of gels by densitometry demonstrated that CAT eluted from the affinity column comprised 65 to $90 \%$ of the protein in the fractions examined in different experiments. From these values, we calculate that CAT was purified at least 95,500 -fold to a specific activity of at least $29.4 \mu \mathrm{mol}$ of acetylcholine formed $/ \mathrm{min} / \mathrm{mg}$ of protein in the experiment shown with $10 \%$ recovery of the CAT activity of the crude homogenate. Affinity-purified CAT was relatively unstable; at $4^{\circ} \mathrm{C}, 20 \%$ of the enzyme activity was lost within $24 \mathrm{hr}$.

Anti-CAT antibodies. Spleen cells from a mouse immunized with affinity-purified CAT were fused with P3X63 Ag8 myeloma cells (see "Materials and Methods"). Hybridoma cells innoculated in 800 wells were incubated for 3 weeks. Ninetysix colonies arose, indicating a $94 \%$ probability of clonality for any hybridoma (De Blas et al., 1981). CAT activity was inhibited by antibodies synthesized by four of the cell lines, which have been named anti-CAT $1,2,3$, and $4 .{ }^{1}$ Anti-CAT 1 was identified as an $\operatorname{IgG}_{2 \mathrm{~b}}$ with $\lambda$ light chains; anti-CAT 2 and 3 were shown to be $\mathrm{IgG}_{1} \mathrm{~s}$ with $\kappa$ light chains, and anti-CAT 4 was identified as IgM with $\kappa$ light chains. The clonal nature of anti-CAT 3 was confirmed by plating at limiting dilutions.

${ }^{1}$ Synonyms for anti-CAT 1, 2, 3, and 4 are 12A8, 12E6, 13E9, and $14 \mathrm{~B} 3$, respectively.
The extent of inhibition of CAT was dependent on both the concentration of enzyme (Fig. 2) and the concentration of antibody (not shown). Incubation of anti-CAT 1, concentrated 25 -fold from spent medium with CAT at concentrations of 1 $\mathrm{nM}$ or less ( $<68 \mathrm{ng}$ of CAT protein $/ \mathrm{ml})$ for $20 \mathrm{hr}$ at $4^{\circ} \mathrm{C}$ resulted in complete inhibition of enzyme activity. As the CAT concentration was increased, the enzyme activity in the presence of anti-CAT 1 approached control values. Anti-CAT 2-conditioned medium concentrated 25 -fold inhibited the synthesis of acetylcholine catalyzed by $0.1 \mathrm{nM}$ CAT ( $6.8 \mathrm{ng}$ of CAT protein/ ml) $88 \%$. Extrapolation of the data for anti-CAT 2 suggests that the antibody secreted by this hybridoma would completely inhibit CAT at enzyme concentrations below $10 \mathrm{pm}$. Incubation of anti-CAT 3 with decreasing concentrations of CAT resulted in a maximum of $80 \%$ inhibition of enzyme activity. A 10 -fold higher concentration of anti-CAT 3 did not inhibit enzyme activity further (not shown).

Analysis of the data by the method of Scatchard (1949) suggested both high and low affinity interactions of anti-CAT 2 with CAT with equilibrium dissociation constants $\left(K_{\mathrm{d}}\right)$ equal to $9.5 \times 10^{-11} \mathrm{M}$ and $2.4 \times 10^{-9} \mathrm{M}$ (Fig. 3). Scatchard analysis of the inhibition of CAT by anti-CAT 3 revealed a single component with a $K_{\mathrm{d}}$ equal to $1.1 \times 10^{-10} \mathrm{M}$.

The inhibition of CAT activity in the presence of anti-CAT 3 resulted from a decrease in $V_{\max }$ for acetylcholine synthesis. The concentration of acetyl coenzyme A or choline in the reaction mixture was varied in the presence of fixed concentrations of the other substrate to determine the reaction kinetics of CAT incubated for $18 \mathrm{hr}$ with either anti-CAT 3 or P3X63 Ag8 antibody. For each enzyme treatment, reciprocal plots of the data resulted in two families of straight lines (Fig. 4). The $K_{\mathrm{m}}$ for choline $(223 \mu \mathrm{M})$ and for acetyl coenzyme A $(27 \mu \mathrm{M})$ were calculated from replots of the slopes and intercepts were extrapolated to saturating concentrations of either substrate (not shown; Florini and Vestling, 1957). Neither $K_{m}$ was affected by a concentration of anti-CAT 3 antibody which inhibited the enzyme by $25 \%$. The $V_{\max }$, calculated from the Henri-Michaelis-Menten equation, was reduced from 111 to 89 $\mathrm{pmol}$ of ACh synthesized/min following incubation of CAT with anti-CAT 3 , demonstrating that a decrease in the maximum rate of the enzyme reaction was responsible for the observed inhibition.

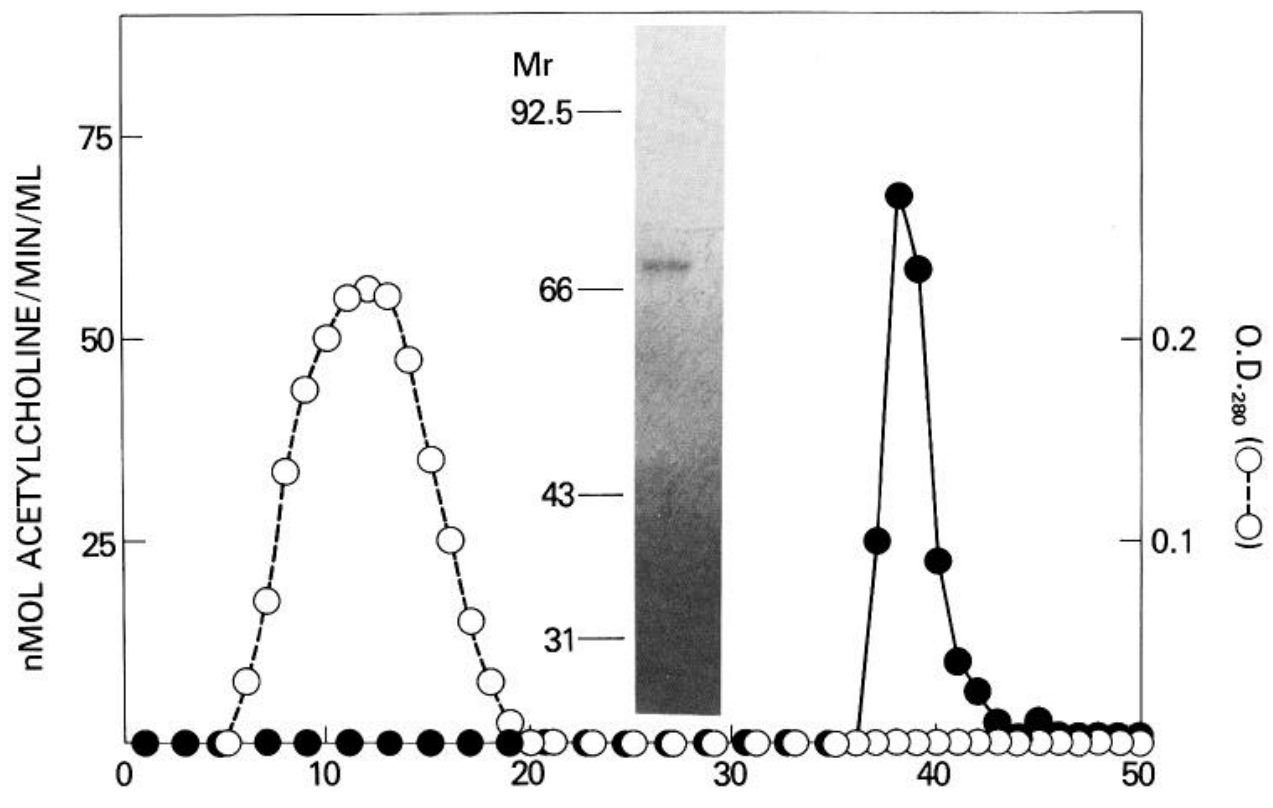

Figure 1. Affinity chromatography of rat choline acetyltransferase on agarose/ hexane/coenzyme A. A portion of the enzyme preparation $(450 \mathrm{nmol}$ of $\mathrm{ACh}$ formed $/ \mathrm{min}$ ) was applied to a $1 \times 6 \mathrm{~cm}$ affinity column in buffer $B$ containing $10 \mathrm{~mm}$ acetylcholine and eluted with 10 $\mathrm{ml}$ of buffer B containing $10 \mathrm{~mm}$ acetyl coenzyme A. CAT activity (-) and protein absorbance at $280 \mathrm{~nm}(O)$ are shown. Inset: SDS-PAGE of purified choline acetyltransferase. The affinity. purified enzyme was subjected to electrophoresis according to the method of Laemmli (1970) and stained with silver ions (Merril et al., 1981). The molecular weight markers were phosphorylase $b$, bovine serum albumin, ovalbumin, and carbonic anhydrase.

FRACTION 


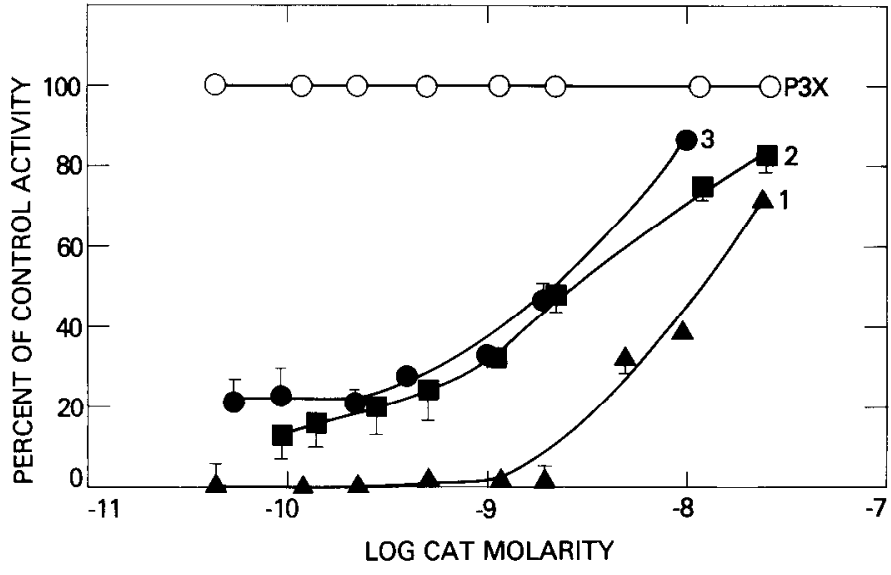

Figure 2. Inhibition of choline acetyltransferase by monoclonal antibodies depends on enzyme concentration. Rat CAT (CM-Sephadex fraction) was incubated with spent medium concentrated 25 -fold from anti-CAT $1(\mathbf{\Lambda}), 2(\square)$, or $3(\mathbf{O})$ for $20 \mathrm{hr}$ at $4^{\circ} \mathrm{C}$ and enzyme activity was measured. Antibody from the parent myeloma P3X63 Ag8 was used as a negative control. The concentration of CAT in each reaction mixture was calculated assuming a theoretical specific activity of 50 $\mu \mathrm{mol}$ of $\mathrm{ACh}$ formed $/ \mathrm{min} / \mathrm{mg}$ of protein. The values are the means \pm $\mathrm{SD}$ of triplicate determinations.

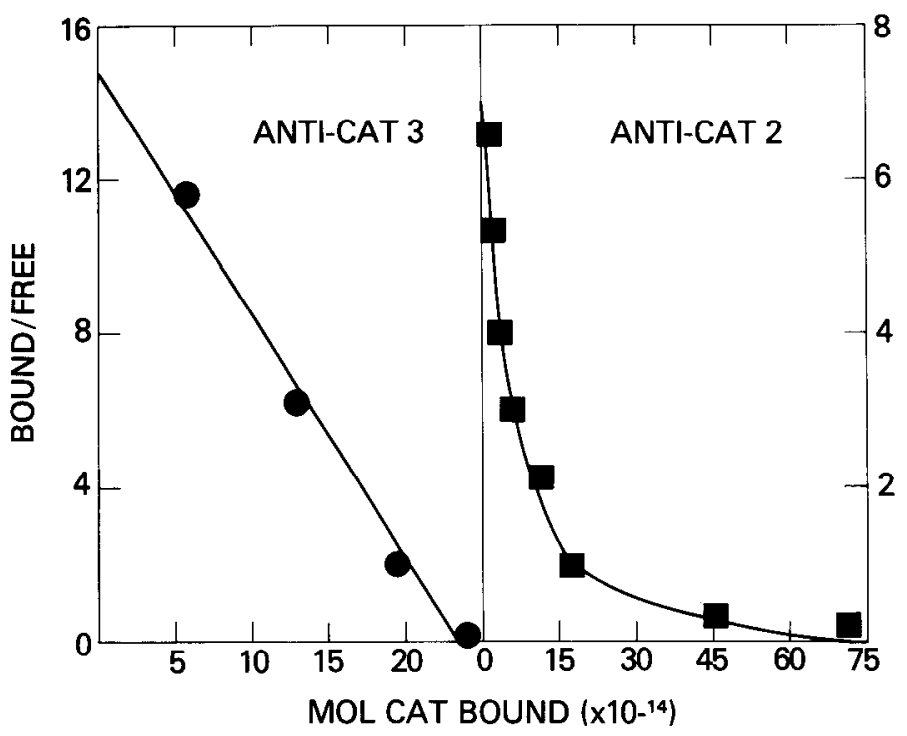

Figure 3. Scatchard analysis of CAT binding to hybridoma antibodies. The data for anti-CAT $2(\square)$ and anti-CAT $3(\bullet)$ in Figure 2 were plotted by the method of Scatchard. The apparent equilibrium constant for the dissociation of [anti-CAT $3 \cdot \mathrm{CAT}$ ] complexes is $1.1 \times$ $10^{-10} \mathrm{M}$. The shape of the Scatchard plot for anti-CAT 2 binding to $\mathrm{C} \Lambda \mathrm{T}$ suggests either multiple kinds of interaction or negative cooperativity.

The antibody-mediated inhibition of CAT activity was reversed by dissociation of [antibody $\cdot$ antigen] complexes (Table II). Incubation of spent medium with enzyme for $20 \mathrm{hr}$ resulted in the loss of 21 to $41 \%$ of the control CAT activity, depending on the antibody preparation. Portions of the reaction mixtures were removed, diluted 10 -fold, and incubated for $2 \mathrm{hr}$ at $4^{\circ} \mathrm{C}$ to promote dissociation of the [enzyme $\cdot$ antibody] complexes. The antibody-dependent inhibitions of CAT decreased when the reaction mixtures were diluted, demonstrating that the inhibitions of CAT by the monoclonal antibodies are reversible.

CAT also was recovered by immunoprecipitation. Formalinfixed $S$. aureus with surface protein A were incubated with saturating concentrations of rabbit anti-mouse IgG for $6 \mathrm{hr}$ at $4^{\circ} \mathrm{C}$, washed twice with $\mathrm{PBS}$, and incubated for an additional
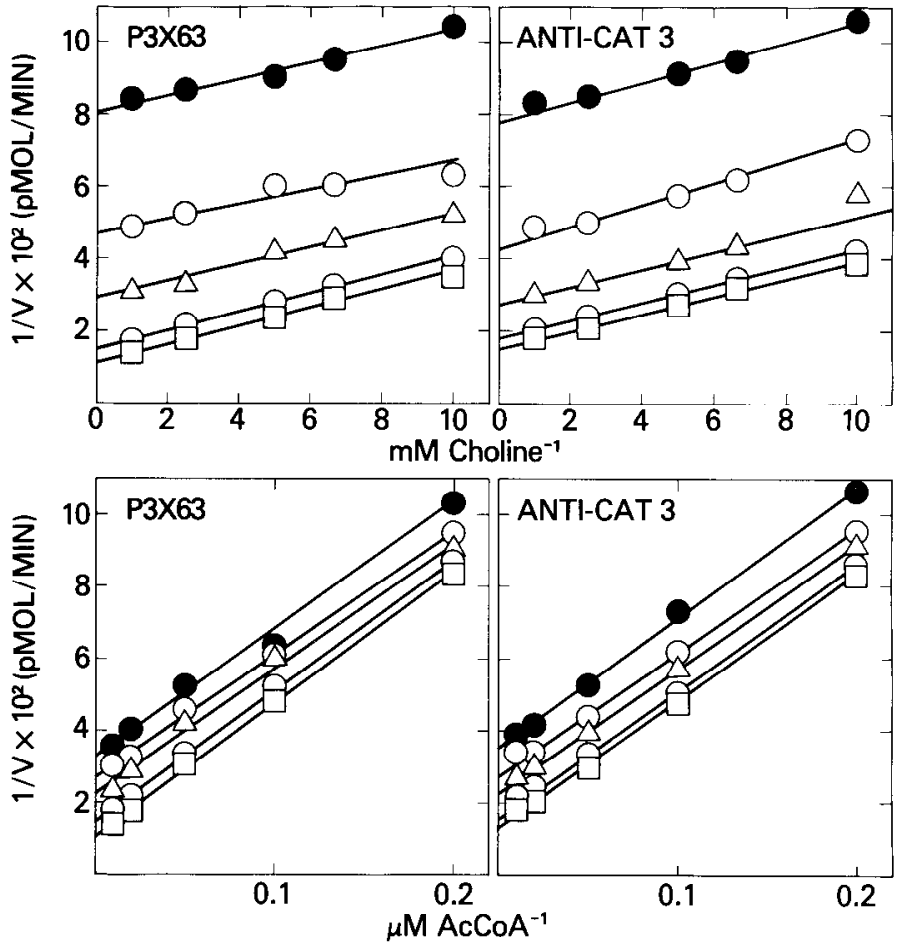

Figure 4. Double reciprocal plots of the activity of rat CAT in the presence of P3X63 Ag8 or anti-CAT 3 antibody as functions of the acetyl coenzyme A or choline concentrations. For the top panels, acetyl coenzyme A concentrations were $5(\bullet), 10(\mathrm{O}), 20(\Delta), 50(\mathrm{O})$, and 100 $\mu \mathrm{M}(\square)$. For the bottom panels, choline concentrations were $0.1(\bullet)$ $0.15(O), 0.2(\triangle), 0.4(O)$, and $1 \mathrm{~mm}(\square)$. Each value is the mean of triplicate determinations. Lines were fitted to the data by linear regression analysis $(r=0.99)$

TABLE II

Reversal of CAT inhibition by dilution-induced dissociation of [antibody.CAT] complexes

Antibodies (conditioned media) were incubated with CAT from rat brain from $20 \mathrm{hr}$ at $4^{\circ} \mathrm{C}(150-\mu \mathrm{l}$ final volume) to promote the formation of [antibody.CAT] complexes. Fifteen- $\mu$ l portions of the reaction mixtures then were removed and diluted 10 -fold with PBS containing $1 \%$ fetal bovine serum, and both undiluted and diluted reaction mixtures were incubated for an additional $2 \mathrm{hr}$ at $4^{\circ} \mathrm{C}$. CAT activities then were assayed as described in "Materials and Methods." Control activity, measured in the presence of antibody produced by the parent myeloma P3X63 Ag8, was $32 \mathrm{pmol}$ of $\mathrm{ACh}$ formed $/ \mathrm{min} / \mu \mathrm{g}$ of protein. Values are the means of triplicate determinations.

\begin{tabular}{ccc}
\hline \multirow{2}{*}{ Antibody } & \multicolumn{2}{c}{ Inhibition } \\
\cline { 2 - 3 } & Not Diluted & Diluted \\
\hline Anti-CAT 1 & 40.8 & 3.38 \\
Anti-CAT 2 & 32.4 & 2.97 \\
Anti-CAT 3 & 34.0 & 7.03 \\
Anti-CAT 4 & 20.7 & 5.00 \\
P3X63 Ag8 & 0 & 0 \\
\hline
\end{tabular}

$24 \mathrm{hr}$ at $4^{\circ} \mathrm{C}$ with a monoclonal antibody. The [monoclonal antibody-rabbit anti-mouse IgG-protein A-bacteria] complexes were collected by centrifugation and incubated with CAT (10 $\mathrm{ng} / \mathrm{ml})$ in PBS containing $1 \%$ fetal bovine serum. The bacteria were recovered by centrifugation, suspended in buffer without CAT, and incubated for $6 \mathrm{hr}$ to promote dissociation of the enzyme from the antibody; 31 to $53 \%$ of the CAT activity lost by formation of the immune complexes was recovered (Table III). The capacities of [monoclonal antibody rabbit anti-mouse IgG • protein A] complexes for CAT were lower than 
TABLE III

Recovery of CAT from immune precipitates

[Monoclonal antibody $\cdot$ rabbit anti-mouse Ig-protein A.S. aureus] complexes were incubated with CAT (1.35 nmol of ACh formed $/ \mathrm{min} /$ $150-\mu \mathrm{l}$ reaction mixture) for $20 \mathrm{hr}$ at $4^{\circ} \mathrm{C}$ and collected by centrifugation, and CAT activity remaining in the supernatant fractions was assayed. Enzyme activity remaining after incubation with monoclonal antibody complexes was subtracted from the CAT activity remaining after incubation with control [rabbit anti-mouse Ig.protein A] complexes to calculate "activity precipitated." The bacterial pellets were suspended in $150 \mu \mathrm{l}$ of PBS containing $1 \%$ fetal bovine serum, incubated for $6 \mathrm{hr}$ at $4^{\circ} \mathrm{C}$ to promote dissociation of CAT, and again collected by centrifugation. CAT activity recovered in the supernatants ("activity eluted") was assayed as described in "Materials and Methods." The enzyme activity recovered from control [rabbit anti-mouse Ig.protein A] complexes (40 pmol ACh formed $/ \mathrm{min} /$ reaction mixture) has been subtracted from the values in the lable. Values are the means of three experiments with triplicate assays in each experiment.

\begin{tabular}{cccc}
\hline Antibody & $\begin{array}{c}\text { Activity } \\
\text { Precipitated }\end{array}$ & $\begin{array}{c}\text { Activity } \\
\text { Recovered } \\
\text { from } \\
\text { Precipitates }\end{array}$ & Recovery \\
\hline & $\begin{array}{c}\text { pmol ACh formed/ } \\
\text { reaction } / \text { min }\end{array}$ & & $\%$ \\
P3X63 Ag8 & 0 & 0 & \\
Anti-CAT 1 & 115 & 48.0 & 41.7 \\
Anti-CAT 3 & 74.5 & 23.5 & 31.5 \\
Anti-CAT 4 & 26.7 & 14.2 & 53.2 \\
\hline
\end{tabular}

TABLE IV

Inhibition of CAT from rat, mouse, and chick by monoclonal antibodies

\begin{tabular}{cccc}
\hline \multirow{2}{*}{ Antibody } & \multicolumn{3}{c}{ Inhibition of CAT } \\
\cline { 2 - 4 } & Rat $^{a}$ & Mouse $^{b}$ & Chick $^{\mathbf{c}}$ \\
\hline P3X63 Ag8 & 0 & 0 & 0 \\
Anti-CAT 1 & 80.2 & 17.0 & 15.9 \\
Anti-CAT 2 & 64.9 & 20.8 & 20.5 \\
Anti-CAT 3 & 28.3 & 26.2 & 5.9 \\
Anti-CAT 4 & 20.7 & & 0 \\
\hline
\end{tabular}

${ }^{a} \mathrm{CM}$-Sephadex fraction; control activity $=7.6 \mathrm{pmol}$ of Ach formed/ $\mathrm{min} /$ reaction mixture. Values are the means of triplicate determinations.

${ }^{h} 40,000 \times g$ supernatant fraction of NS20-Y mouse neuroblastoma in PBS; control activity $=11.8 \mathrm{pmol}$ Ach formed $/ \mathrm{min} / \mathrm{reaction}$ mixture.

${ }^{c} 40,000 \times g$ supernatant of 18 -day chick embryo brain in PBS; control activity $=9.7 \mathrm{pmol}$ Ach formed $/ \mathrm{min} /$ reaction mixture.

an equivalent amount of free anti-CAT antibody, presumably due to steric hindrance of CAT binding. No CAT activity was precipitated by complexes formed with anti-CAT 2 in three experiments (not shown).

The specificity of the monoclonal antibodies for CAT from rat brain, mouse NS-20Y neuroblastoma cells (Amano et al., 1972), and chick brain is shown in Table IV. Monoclonal antibodies 1, 2, and 3 inhibited CAT from each source tested. The extent of inhibition was greatest with the rat enzyme. Anti-CAT 4 inhibited CAT from rat, but not chick brain. However, anti-CAT 4 bound to CAT from chick brain as evidenced by the precipitation of enzyme by this antibody in the presence of rabbit anti-mouse IgG and protein A (not shown).

\section{Discussion}

Choline acetyltransferase was purified 95,000-fold from whole rat brain by a modification of the method of Ryan and McClure (1979). The procedure was improved by the use of a commercially available affinity column resin, coenzyme A coupled to an agarose-hexanoic acid support by carbodiimide reaction which yields a product with free sulfhydryl groups. This affinity chromatography step resulted in a 900 -fold purification of CAT, compared to purification of CAT on either blue dextran (Dietz and Salvaterra, 1980) or coenzyme A-Sepharose (Ryan and McClure, 1979) which yield 39- and 80-fold purifications, respectively. In addition, the procedure described in this paper involves fewer steps than previously published methods.

Hydrophobic and hydrophilic interactions have been reported between choline acetyltransferase and several affinity resins (Malthe-Sørenssen et al., 1978; Ryan and McClure, 1979; Dietz and Salvaterra, 1980). In order to reduce the role of nonspecific interactions of CAT during chromatography on coenzyme A $\cdot$ hexane $\cdot$ agarose, both $20 \%$ ethylene glycol and 200 $\mathrm{mM} \mathrm{NaCl}$ were included in the buffer when the enzyme was applied to the column. Ten mM acetylcholine was added to the sample application buffer to increase the specificity of CAT binding to the resin. Acetylcholine has been shown to increase the affinity of CAT for coenzyme A (White and Wu, 1973). ${ }^{2}$

Our estimate of the specific activity of homogeneous rat brain CAT $(45 \mu \mathrm{mol}$ of acetylcholine formed $/ \mathrm{min} / \mathrm{mg}$ of protein) is somewhat lower than those reported by Ryan and McClure (1979) and Dietz and Salvaterra (1980), 60 and 77 $\mu \mathrm{mol}$ of acetylcholine formed $/ \mathrm{min} / \mathrm{mg}$ of protein, respectively. The difference may stem from the method of determining the protein concentration of the final enzyme preparation. In this report, protein was determined by the fluorescamine assay of Böhlen et al. (1973), while previous estimates were made by comparing Coomassie blue staining densities of standards and unknowns on SDS-polyacrylamide gels.

The detection of monoclonal antibodies to an antigen that has not been purified to homogeneity requires a highly specific method of assay. The monoclonal antibodies described in this report were detected by their ability to inhibit CAT activity. This approach was chosen because: (1) the assay does not depend on the purity of the enzyme preparation; (2) antibodies that affect enzyme activity may be useful not only as histochemical reagents, but also in studies of the reaction mechanism; and (3) epitopes which modulate enzyme activity are likely to be conserved during evolution. In fact, three of four antibodies were found to inhibit CAT from rat, mouse, and chick. Not all antibodies that inhibit CAT activity need crossreact with other species. For example, Crawford et al. (1982a) have shown that antibodies that inhibit Drosophila brain CAT do not interact with CAT from other species tested.

Anti-CAT 1 or 2 inhibits CAT activity $100 \%$. In contrast anti-CAT 3 apparently inhibits the enzyme by only $80 \%$. Further work is required to determine whether all CAT molecules are inhibited partially by anti-CAT 3 or whether the enzyme preparation contains two or more forms of CAT that differ in their sensitivity to inhibition by anti-CAT 3 . In several reports, multiple CAT isozymes have been detected by means of isoelectric focusing (Malthe-Sørenssen and Fonnum, 1972), fractionation of cellular components (Smith and Carroll, 1980), and peptide mapping (Dietz and Salvaterra, 1980). Whether these results reflect post-translational modifications of a single gene product or the products of multiple genes is not known. The monoclonal antibodies described in this report may be useful reagents for the identification of cDNA clones corresponding to CAT mRNA(s) allowing the direct study of transcriptional and translational regulation of the CAT gene(s).

\footnotetext{
${ }^{2}$ We are uncertain whether repetitive use of this resin results in the slow enzymatic acetylation of coenzyme $A$ residues and thereby alters the column parameters. A small loss of purification was noted when the column had been used six times.
} 


\section{References}

Amano, T., E. Richelson, and M. Nirenberg (1972) Neurotransmitter synthesis by neuroblastoma clones. Proc. Natl. Acad. Sci. U. S. A. 69: $258-263$.

Böhlen, P., S. Stein, W. Dairman, and S. Udenfriend (1973) Fluorometric assay of proteins in the nanogram range. Arch. Biochem. Biophys. 155: 213-220.

Crawford, G., J. R. Slemmon, and P. M. Salvaterra (1982a) Monoclonal antibodies selective for Drosophila melanogaster choline acetyltransferase. J. Biol. Chem. 257: 3853-3856.

Crawford, G. D., L. Correa, and P. M. Salvaterra (1982b) Interaction of monoclonal antibodies with mammalian choline acetyltransferase. Proc. Natl. Acad. Sci. U. S. A. 79: 7031-7035.

DeBlas, A. L., M. V. Ratnaparkhi, and J. E. Mosimann (1981) Estimation of the number of monoclonal hybridomas in a cell fusion experiment. Effect of post-fusion cell dilution on hybridoma survival. J. Immunol. Methods 45: 109-115.

Dietz, G. W., Jr., and P. M. Salvaterra (1980) Purification and peptide mapping of rat brain choline acetyltransferase. J. Biol. Chem. 255: 10612-10617.

Eckenstein, F., Y.-A. Barde, and H. Thoenen (1981) Production of specific antibodies to choline acetyltransferase purified from pig brain. Neuroscience 26: 993-1000.

Florini, J. R., and C. S. Vestling (1957) Graphical determination of the dissociation constants for two substrate enzyme systems. Biochim. Biophys. Acta 25: 575-578.

Galfre, G., S. C. Howe, C. Milstein, G. W. Butcher, and J. C. Howard (1977) Antibodies to major histocompatability antigens produced by hybrid cell lines. Nature 266: 550-552.

Ichikawa, T., I. Ishida, and T. Deguchi (1983) Monoclonal antibodies to choline acetyltransferase of rat brain. FEBS Lett. 155: 306-310.

Laemmli, U. K. (1970) Change of structural proteins during the assembly of the head of bacteriophage $\mathrm{T}_{4}$. Nature 227: 680-685.

Le Douarin, N. M. (1980) The ontogeny of the neural crest in avian embryo chimaeras. Nature 286: 663-669.

Levey, A. I., M. Aoki, F. W. Fitch, and B. H. Wainer (1981) The production of monoclonal antibodies reactive with bovine choline acetyltransferase. Brain Res. 218: 383-387.

Levey, A. I., D. M. Armstrong, S. F. Atweh, R. D. Terry, and R. H. Wainer (1983) Monoclonal antibodies to choline acetyltransferase: production, specificity, and immunohistochemistry. J. Neurosci. 3: $1-9$.

Lowry, O. H., N. J. Rosebrough, A. L. Farr, and R. J. Randall (1951) Protein measurement with the Folin phenol reagent. J. Biol. Chem. 193: 265-275.

Malthe-Sørenssen, D., and F. Fonnum (1972) Multiple forms of choline acetyltransferase in several species demonstrated by isoelectric focusing. Biochem. J. 127: 229236.

Malthe-Sørenssen, O., T. Lea, F. Fonnum, and T. Eskeland (1978) Molecular characterization of choline acetyltransferase from bovine brain caudate nucleus and some immunological properties of the highly purified enzyme. J. Neurochem. $30: 35-46$.

Merril, C. R., D. Goldman, S. A. Sedman, and M. H. Ebert (1981) Ultrasensilive stain for proteins in polyacrylamide gels shows regional variation in cerebrospinal fluid proteins. Science $211: 1437-$ 1438.

Park, D. H., M. E. Ross, V. M. Pickel, O. J. Reis, and T. H. Joh (1982) Antibodies to rat choline acetyltransferase for immunochemistry and immunocytochemistry. Neurosci. Lett. 34: 129-135.

Patterson, P. H. (1979) Epigenetic influences in neuronal development. In The Neurosciences, Fourth Study Program, F. O. Schmitt and F. G. Worden, eds., pp. 929-936. MIT Press, Cambridge, MA.

Ryan, R. L., and W. O. McClure (1979) Purification of choline acetyltransferase from rat and cow brain. Biochemistry 18: 5357-5365.

Scatchard, G. (1949) The attractions of proteins for small molecules and ions. Ann. N. Y. Acad. Sci. 51: 660-672.

Schrier, B. K., S. H. Wilson, and M. Nirenberg (1974) Cultured cell system and methods for neurobiology. Methods Enzymol. 32: 765788.

Smith, C. P., and P. T. Carroll (1980) A comparison of solublized and membrane bound forms of choline $O$-acetyltransferase (EC 2.3.1.6) in mouse brain nerve endings. Brain Res. 185: 363-371.

Trisler, G. D., M. D. Schneider, and M. Nirenberg (1981) A topographic gradient of molecules in retina can be used to identify neuron position. Proc. Natl. Acad. Sci. U. S. A. 78: 2145-2149.

Walicke, P. A., Campenot, R. B., and Patterson, P. H. (1977) Determination of transmitter function by neuronal activity. Proc. Natl. Acad. Sci. U. S. A. 74: 5767-5771.

Weber, M. J. (1981) A diffusable factor responsible for the determination of cholinergic functions in cultured sympathetic neurons. Partial purification and characterization. J. Biol. Chem. 256: 3447-3453.

White, H. L., and J. C. Wu (1973) Kinetics of choline acetyltransferases (EC 2.3.1.6) from human and other mammalian central and peripheral nervous tissues. J. Neurochem. 20: 297-307. 